\title{
Chitosan Added as an Antimicrobial in Edible Film and Its Application to The Dodol of Seaweed (Eucheuma cottonii L.)
}

\author{
Warkoyo $^{1)}$, Noor Harini ${ }^{1)}$, David Hermawan ${ }^{2)}$, Yuliarie Wulandari ${ }^{1)}$ \\ 1) Department of Food Science and Technology, University of Muhammadiyah Malang, Indonesia \\ ${ }^{2)}$ Departement of Aquaculture, University of Muhammadiyah Malang, Indonesia
}

\begin{abstract}
Eucheuma cottonii L. seaweed contains dietary fiber that can cure some degenerative diseases. Dodol seaweed without preservatives can be an alternative as a functional food that many people need to maintain their health. Generally dodol made with the addition of preservatives to enhance the shelf life. Dodol without preservative makes its easily microbes growth and oxidized, thus making it quickly damaged and not accepted by consumers. The use of active edible film on dodol seaweed is expected to inhibit damage and prolong the shelf life. Chitosan is one of the recommended hydrophobic biopolymers to improve the film characteristics based starch while having antimicrobial activity. The purpose of this research is to know the effect of chitosan concentration on character of edible film, and the effect of its application on weight loss, texture and microbial quantity on dodol seaweed in the storage period. The research results showed that the addition of chitosan can increase tensile and transparency, and decrease of elongation and WVTR edible film. Active edible film application has been shown to inhibit the damage of dodol seaweed during the storage period compared without active edible film and inhibiting microbial growth.
\end{abstract}

\section{Introduction}

Seaweed contain diaetary fiber. Dodol seaweed without preservatives can be an alternative as a functional food that many people need to maintain their health. Without preservatives, food product becomes good medium for microbial growth, thus making its quickly damaged and not accepted by consumers. The use active edible film to dodol seaweed is expected to inhibit the damage.

Seaweed, in addition to containing nutrients such as carbohydrates, proteins, fats, and minerals, also contains crude fiber and dietary fiber that can provide the function of treating some degenerative diseases, so it can be processed into functional food. One possible form of preparation is dodol. Dodol is generally made by adding inorganic preservatives to increase shelf life, but the presence of preservatives makes its unsafe if consumed in the long time. While dodol without preservatives will be easily damaged by microbes and oxidation, thus making it unacceptable to consumers.

${ }^{1}$ Corresponding author: warkoyo@umm.ac.id 
Associated with these problems, the researchers provide solutions with the application of active edible film based taro tuber starch with the addition of chitosan active ingredients on dodol seaweed without inorganic preservatives. The advantages of using active edible film among others can be consumed directly with packaged products, do not pollute the environment, improve the organoleptic properties of packaged products, as flavors, dyes, antimicrobial agents, and antioxidants. Chitosan as a hydrophobic biopolymer is added with the intent as disclosed by Chillo et al. [1] that to improve the film characteristics of hydrophilic starch susceptible to water vapor transmission [2] and simultaneously act as antimicrobials. The aim of this research is to determine the edible character of active films due to the addition of chitosan and to determine the effect of active edible film application on dodol seaweed during storage.

\section{Material and Methods}

The main ingredients used in this research are taro tuber as an ingredient of edible film, seaweed obtained from seaweed collector of area Sumenep Madura, glutinous rice flour, rice flour obtained from foodstuff and chitosan store obtained from chemical store Makmur Sejati Malang

The study was divided into 2 stages, namely that is making of active edible film with chitosan addition $(1,2,3 \%)$ as antimicrobial material as first stage, then measured its physical character. The physical parameters of edible film include thickness, tensile [3], elongation [3], WVTR [4] and transparency [5]. Further applied to wrapping dodol seaweed to the functional test with a store period of $0,2,4,6$ days as second stage. Among the functional test parameters in dodol include weight loss [6], hardness rate, and microbial count (TPC) [7].

\section{Result and Discussion}

\subsection{Characteristics of Edible film}

Characteristics of edible film based taro tuber starch due to the addition of chitosan are presented in Table 1.

Table 1. Characteristics of edible film based taro tuber starch due to the addition of chitosan

\begin{tabular}{cccccc}
\hline Chitosan & $\begin{array}{c}\text { Thickness } \\
(\mathrm{mm})\end{array}$ & $\begin{array}{c}\text { Tensile } \\
\text { Strenght } \\
(\mathrm{M} . P a)\end{array}$ & $\begin{array}{c}\text { Elongation } \\
(\%)\end{array}$ & $\begin{array}{c}\text { WVTR }(\text { g.m } \\
\left.{ }^{-} \text {. } \text { day }^{-1}\right)\end{array}$ & $\begin{array}{c}\text { Transparance } \\
\left(\mathrm{mm}^{-1}\right)\end{array}$ \\
\hline $1 \%$ & $0.09 \mathrm{a}$ & $1.33 \mathrm{a}$ & $87.47 \mathrm{c}$ & $8.23 \mathrm{c}$ & $4.89 \mathrm{a}$ \\
$2 \%$ & $0.11 \mathrm{a}$ & $1.75 \mathrm{ab}$ & $62.78 \mathrm{~b}$ & $7.77 \mathrm{~b}$ & $5.27 \mathrm{ab}$ \\
$3 \%$ & $0.10 \mathrm{a}$ & $2.50 \mathrm{~b}$ & $43.21 \mathrm{a}$ & $5.45 \mathrm{a}$ & $6.17 \mathrm{~b}$ \\
\hline
\end{tabular}

\subsubsection{Thickness}

The thickness of edible active film produced ranges from 0.09 to $0.11 \mathrm{~mm}$, this result meets the Japanese industry standards, ie a maximum thickness of $0.25 \mathrm{~mm}$. The thickness obtained slightly increased in the presence of increased chitosan concentration, which increased by 0.005 times the concentration of chitosan (Figure 1). This occurs because the difference in chitosan concentration does not produce the viscosity of different edible film 
solutions. The addition of the active ingredient in edible film tends to increase its thickness $[8,9]$

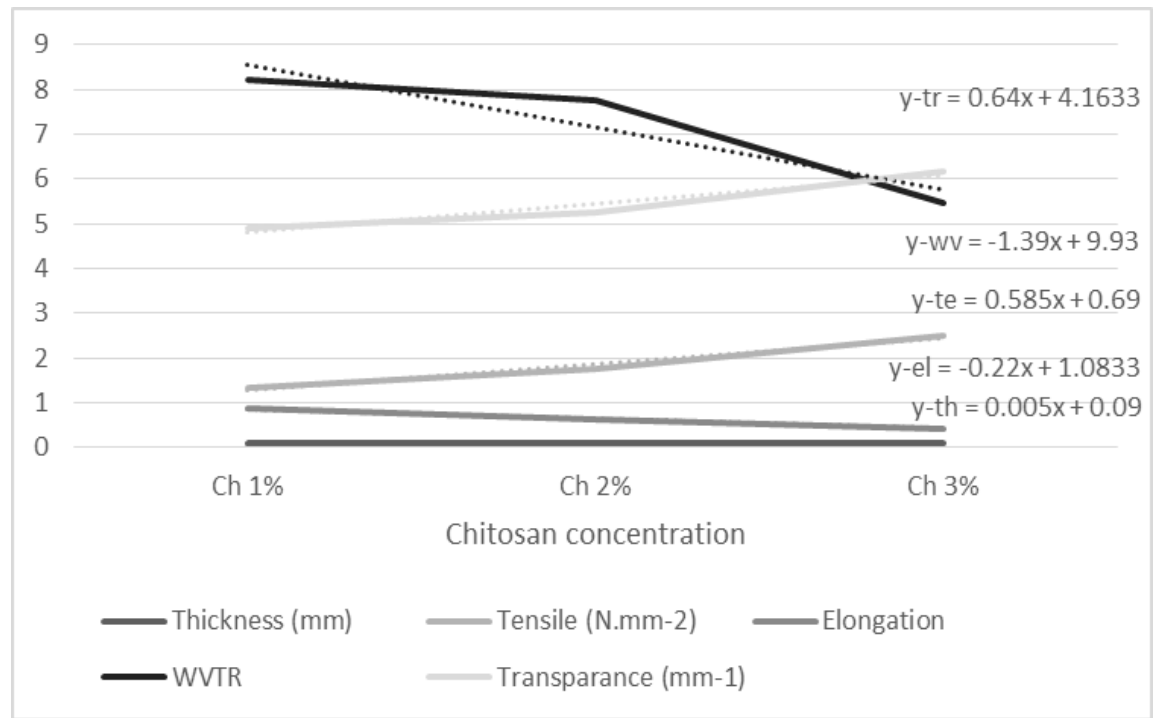

Fig 1. The character of the active edible film due to different of chitosan concentrations

In principle, the more constituent components are added, the thickness of edble film increases. That is supported by the opinion of Nugroho et al [10] which states that the increase in the solids amount in solution causes the polymers that make up the edible film matrix more and more. In addition to the total solids in the solution, other things that affect the edible thickness are the viscosity and the constituent polymer content.

\subsubsection{Tensile Strength}

The tensile strength of the film increases with the added chitosan concentration (Figure 1). The tensile increases with chitosan added, which is 0.585 times, its value ranges from 1.33 to $2.50 \mathrm{MPa}$, the value available with the Japan Industry Standard (at least 0.39 M.Pa). This shows that the greater chitosan concentration added to edible film production has an effect on the higher tensile strength value. While the research results Warkoyo et al and Lim et al $[8,9]$ states that the added active ingredients tend to lower the tensile of edible film.

That is happen because chitosan acts as an antimicrobial as well as a film-forming matrix, so the greater the tensile strength value is influenced by the addition of more chitosan, the matrix that is formed will also increase, and the thickness of the film increases, the result is stronger, so the strength which is given to attract bigger. Increased tensile strength shows resistance to damage due to stretching and greater pressure, resulting in improved physical quality of edible film

\subsubsection{Elongation}

The elongation of edible film increased with higher chitosan concentrations (Figure 1). Based on Japan Industrial Standart, the resulting elongation (43 - 87\%) is good (10-50\%) to very good (more than 50\%.) Elongation is an edible elasticity percentage, the magnitude is inversely proportional to tensile. That is happen because the edible nature of the film is 
affected by the major constituent components and the amount of active ingredient added, both the type and the level [8]. The higher the concentration of chitosan will affect the viscosity of the edible film solution prior to printing. In addition, it is also influenced by the addition of plasticizer, the increased concentration of dissolved chitosan without being accompanied by an increase in plasticizer concentration will result in a more rigid edible film resulting in lower elongation values associated with the increasing amount of dissolved solids.

\subsubsection{Water Vapor Transmission Rate (WVTR)}

The water vapor transmission rate of edible films decreases with the greater chitosan concentration added, and compared to JIS standard (maximum 7 g.m $\mathrm{m}^{-2}$.day ${ }^{-1}$ ) the edible film available is edible film with $3 \%$ chitosan addition. A low WVTR value indicates the edible film is capable of inhibiting the transmission of water vapor, or is not easy for water vapor to pass. The high value of water vapor transmission is influenced by the ratio of hydrophobic and hydrophilic materials. In addition, The value of the transmission rate is inversely proportional to the thickness value. The thicker the film, the lower the water vapor transmission rate because the thickness is the distance that must be taken by water vapor to diffuse through the film, so the thicker the film, the longer the distance and takes a long time.

\subsubsection{Transparency}

The greater the concentration of chitosan addition the higher the transparency value with the other meaning the more opaque the edible film produced. The transparency value of edible film may be affected by its thickness and constituent components. The thicker the film, the higher the transparency value. And the color produced by chitosan is yellowish, the greater the concentration of chitosan that is added, the greater the yellowish edible degree. This is because more and more light is absorbed on the sheet of film shot by a spectrophotometer with a certain wavelength. The transparency of a sample will be proportional to the thickness and concentration.

\subsection{Functional test}

\subsubsection{Weight loss of dodol}

Weight loss of dodol due to active edible film during storage increased at a low rate of 0.03 , while in the dodol without edible film increased at a relatively fast rate of 2 times (Figure 2). The lower the rate of weight loss, the reduction of moisture content during storage is smaller, consequently the freshness of dodol can be maintained. According to Shen et al. (2010) additions to certain limits, the active ingredients will modify the structure of the starch tissue, the film becomes brittle and moisture is easy through it.

Weight loss dodol due to active edible film application is no different from the low rate of increase. That is due to WVTR of the 3 edible films used is very low, ranging from 5-8 g. $\mathrm{m}^{-2}$. day ${ }^{-1}$. The greater the weight loss value means the greater the water vapor coming out of the material, the worse the packaging material is in preventing product damage. Factors that cause increased weights of weight loss during storage are loss of water content and other volatile compounds during storage. In addition, the weight loss correlated positively with the thickness of the edible film 


\subsubsection{Texture of Dodol}

The texture of dodol seaweed due to different active edible film is presented in Figure 3. The harder the product the greater the force required to puncture the product. Dodol with active edible film treatment of is relatively unchanged texture, while dodol texture without edible active film during the store period decreases, the power to suppress the dodol is getting smaller, meaning dodol is getting soft. That indicates that the active film edible treatment is capable of inhibiting dodol damage, so that during the 6-day shelf period the dodol texture has not changed. Warkoyo et al. [11]reduced texture rate decreases with the addition of potassium sorbet active ingredients more and more. The texture of the filet with edible coating is harder than the texture of the filet without the edible coating [13].

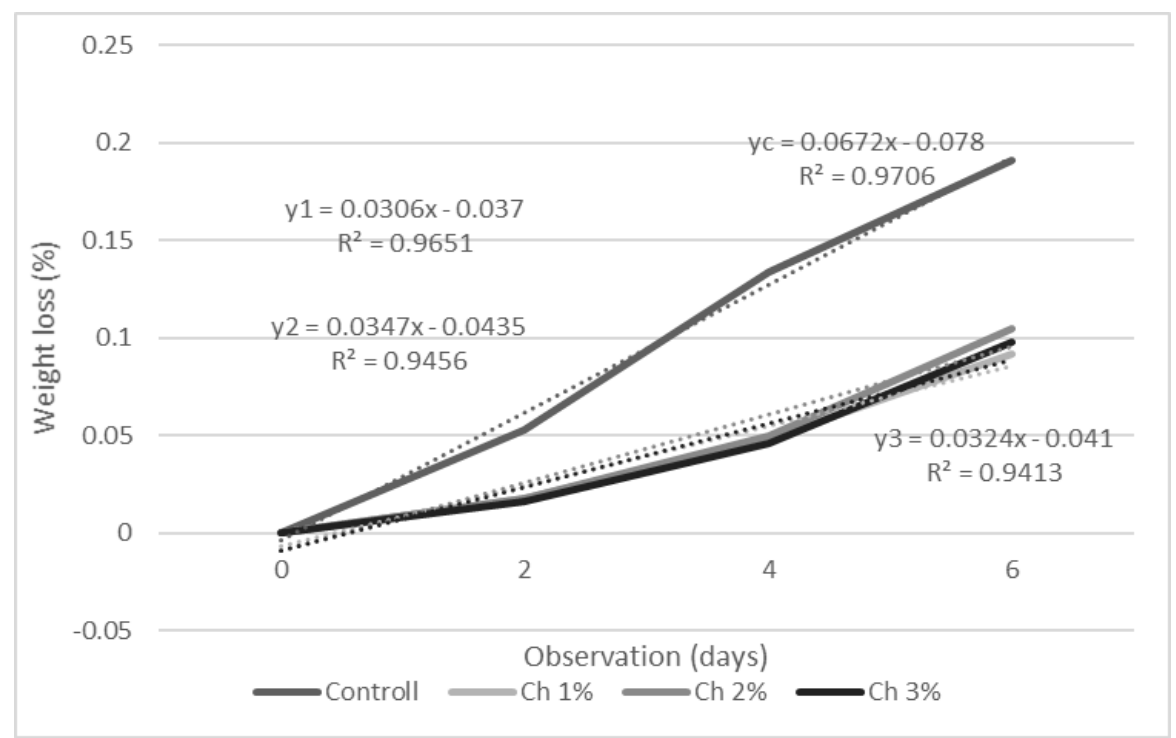

Fig 2. The weght loss of dodol seaweed due to edible film with different chitosan concentrations during the store period 


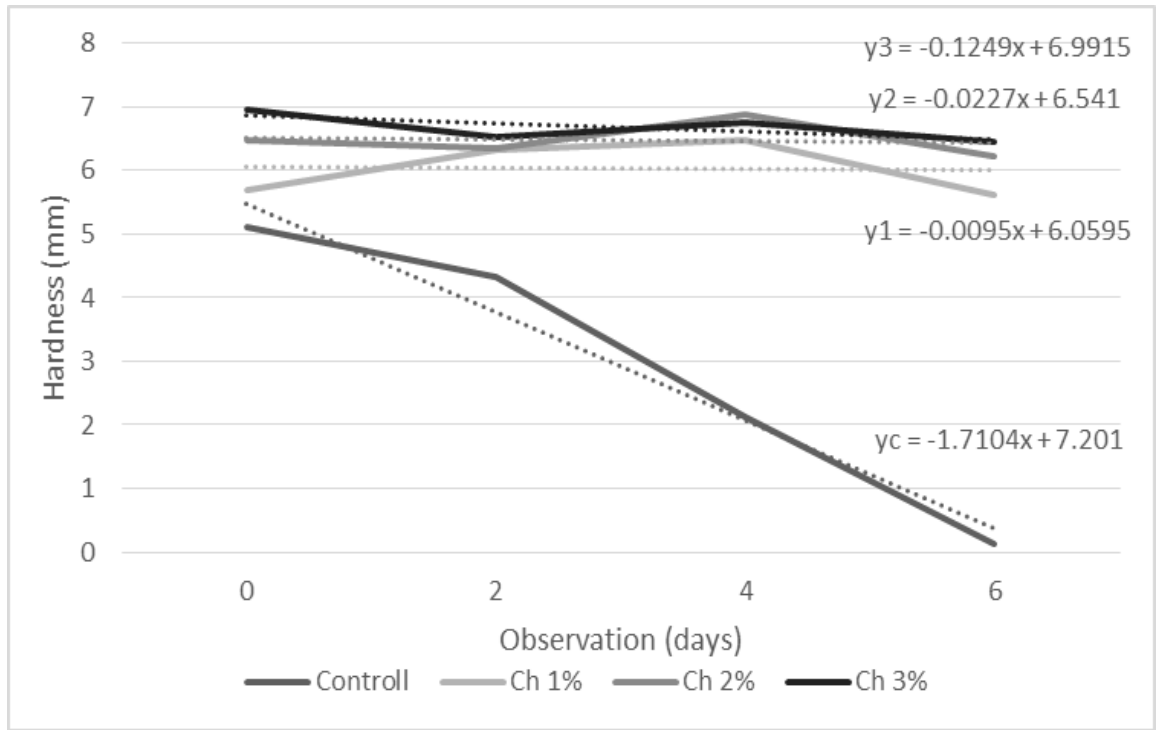

Fig 3. Texture of dodol seaweed due to edible film with different chitosan concentrations during the store period

The main factor affecting dodol texture during storage is the influence of edible film coating, each type of edible film has different physical characteristics and effect on dodol texture value during storage. While texture changes during storage can be caused by retrogradation, enzymatic reactions, and water absorption as well as increased oxidation reactions. The effect of water absorption depends on the level of the product's water content and its texture characteristics, in which water may increase or disappear during storage.

\subsubsection{Mikrobes Number (TPC)}

The number of microbes in dodol due to the application of active edible films during the store period is presented in Figure 4. The number of microbes in dodol due to active edible film application is changed linearly, while in dodol without active edible film changes exponentially. This is in accordance with the research of Warkoyo et al. [11], that the increasing amount of potassium sorbet, resulting in smaller amounts of microbial and increasingly sloping graphics, and its products are increasingly durable. The same results were also produced by Juck et al [12] in boiled chicken with edible application of starchbased film that incorporated potassium sorbet. 


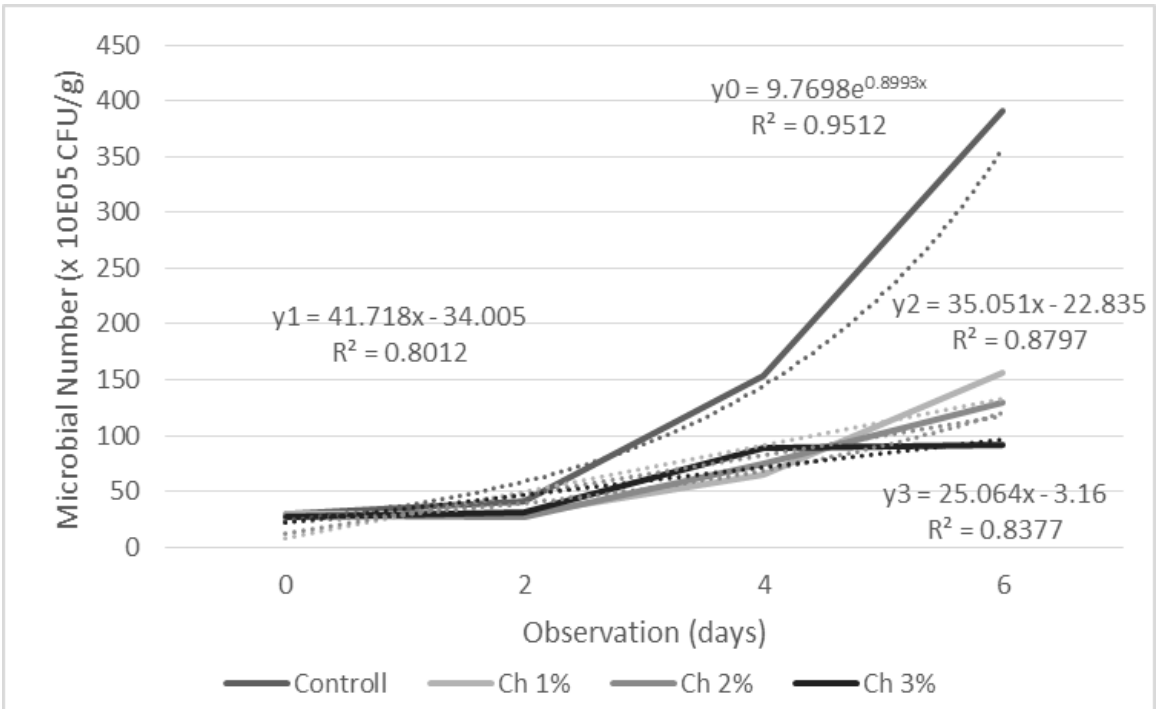

Fig 4. Microbes number (TPC) in dodol seaweed due to edible films with different chitosan concentrations during the store period

Some factors that influence, in addition to the influence of coating type of edible film is also based on the data mentioned above it is proved that edible film is able to inhibit the growth of microorganisms during storage. During the storage process, growth and development of mold and various microbes are inhibited by the presence of chitosan. Chitosan has antimicrobial properties by inhibiting the development of cells that have a negative charge. The concentration of the constituents of the edible film is certainly influential on the inhibition of microbes growth.

\section{Conclusion}

The research result showed chitosan concentration can effect the character of edible film and dodol seaweed. The addition of chitosan in edible film can increase to thickness, tensile strength, and WVTR, and can decrease to elongation and transparency. The use of active edible film to dodol seaweed can maintain its quality, and weight loss is inhibited to $50 \%$, hardness rate is inhibited up to 10 times compare to without edible film. Microbial number (TPC) can be effectively inhibited until $6^{\text {th }}$ day for $3 \%$ chitosan addition, with linear growth while microbial on dodol without edible grow exponentially.

\section{References}

1 S. Chillo, S. Flores, M. Mastromatteo, A. Conte, L. Gerschenson, And M.A. Del Nobile. J. Food Engin. 88,159-168 (2008)

2 M. A. Garcia, M. N. Martino, and N. E. Zaritzky. Journal Of Food Sci. 65, 94-947 (2011)

3 ASTM. Standard test method for tensile properties of thin plastic sheeting, Annual books of ASTM standards. (Designation E96-01. Philadelphia: ASTM, 2001a)

4 ASTM. Standard test method for water vapor transmission of materials. Annual books of ASTM standards. (Designation D882-01. Philadelphia: ASTM, 2001b) 
5 A.A. Al-Hasan, and M.H. Norziah. Food hydrocolloids. 26,108-117 (2012)

6 P. Suppakul, K. Jutakorn, and Y. Bangchokedee. J. Food Engin. 98, 207-213 (2010)

7 E.A. Yousef, and C. Carlstrom. Food Microbiology: a Laboratory Manual. (A John Wiley and Sons., Inc. Publication, USA, 2003)

8 Warkoyo, B. Rahardjo, Dj. W. Marseno, and J. N. W. Karyadi. Jurnal Agritech. 34, 72$81(2014)$

9 G.O. Lim, S.A. Jang, K.B. Song. Journal of Food Engin. 98, 585-593 (2010)

10 A. A. Nugroho, Basito, and R. B. Katri. Jurnal Teknosains Pangan. 2, 73-79 (2013)

11 Warkoyo, B. Rahardjo, Dj. W. Marseno, and J. N. W. Karyadi. Jurnal Agritech. 35, 6168 (2015)

12 G. Juck, H. Neetoo, H. Chen.. Int. J. of Food Microbiol. 142: 302-308 (2010)

13 S.M. Ojagh, M. Rezaei, S.H. Razavi, S.M.H. Hosseini. Food Chemistry. 120, 193-198 (2010)

14 X.L. Shen, J.M. Wu, Y. Chen, G. Zhao. Food Hydrocolloids. 24, 285-290 (2010) 